\title{
Parallel adaptive patterns of allozyme and inversion polymorphisms on an ecological gradient
}

\author{
MARIANA MATRAJT, VIVIANA CONFALONIERI* $† \&$ JUAN VILARDI $\dagger$ \\ Laboratorio de Genética, Dto. Cs. Biológicas, Fac. Cs. Exactas y Naturales, Universidad de Buenos Aires, \\ 1428 Buenos Aires, Argentina
}

\begin{abstract}
Trimerotropis pallidipennis is an American grasshopper whose South American populations are polymorphic for pericentric inversions. The frequencies of some of these rearrangements are correlated with geographical and climatic variables, following similar patterns among different ecological gradients. Hence, this species constitutes a promising model in which the evolutionary significance of inversion systems can be analysed as possible sources of coadapted groups of linked genes. Six samples collected along an altitudinal gradient were assayed jointly for genetic and chromosomal variation. Interestingly, the phenograms constructed with Nei's genetic distances obtained from allozyme and chromosome data were almost identical. This result is produced mainly by esterase loci variation, probably as a consequence of linkage disequilibrium. The evolutionary significance of this association is briefly discussed.
\end{abstract}

Keywords: gradients, inversions, isozymes, linkage disequilibrium, natural selection, Orthoptera.

\section{Introduction}

It is argued that inversion polymorphisms are often related to particular environments because of their ability to generate coadapted supergenes maintained by selection.

Trimerotropis pallidipennis is an American grasshopper whose South American populations are polymorphic for pericentric inversions (Mesa, 1971; Vaio et al., 1979; Goñi et al., 1985; Confalonieri, 1988), North American ones being monomorphic (White, 1951). Most of the species of this genus inhabit arid regions from western North America; T. pallidipennis is one of the few Trimerotropines to have extended its distribution successfully to Andean South America (White, 1973). Previous studies revealed that the frequencies of some inversions are correlated with geographical variables such as altitude, longitude and latitude. These clinal variations have similar characteristics among different geographical gradients and are temporally stable. Hence, there is evidence for the deterministic origin of these

${ }^{*}$ Correspondence.

$\dagger$ Members of the Consejo Nacional de Investigaciones Científicas y Técnicas patterns, the possible selective agents being minimum temperature and humidity (Confalonieri \& Colombo, 1989, 1992; Confalonieri, 1994).

Recent work has revealed that the level of genetic differentiation among samples belonging to different geographical areas is associated with a high degree of chromosomal divergence which suggested a possible adaptation of the corresponding supergenes to the particular ecological conditions (Confalonieri et al., 1990, 1992).

In order to gain insight into the causes of maintenance of inversion polymorphisms in natural populations, six new samples of T. pallidipennis, belonging to the same geographical area and collected along an altitudinal gradient, were assayed jointly for genetic and chromosomal variation. Parallel patterns of distribution of two enzymatic loci and two chromosome sequences were observed and are reported here.

\section{Materials and methods}

A total of 166 adult grasshoppers were collected from six Argentine populations: Chosmes (CHO), Observatorio (OBS), Tunuyán (TUN), Cacheuta (CAC), Uspallata (USP) and Puente del Inca (PTI) 
Table 1 Geographical and climatic characteristics of Trimerotropis pallidipennis collected in Chosmes (CHO), Observatorio (OBS), Tunuyán (TUN), Cacheuta (CAC), Uspallata (USP) and Puente del Inca (PTI)

\begin{tabular}{lccccccrr}
\hline Population & $\begin{array}{c}\text { Altitude } \\
(\mathrm{m})\end{array}$ & $\begin{array}{c}\text { Latitude } \\
(\text { degrees })\end{array}$ & $\begin{array}{c}\text { Longitude } \\
(\text { degrees })\end{array}$ & $\begin{array}{c}\text { Maximum } \\
\text { temp. }\left({ }^{\circ} \mathrm{C}\right)\end{array}$ & $\begin{array}{c}\text { Minimum } \\
\text { temp. }\left({ }^{\circ} \mathrm{C}\right)\end{array}$ & $\begin{array}{c}\text { Humidity } \\
(\%)\end{array}$ & $\begin{array}{r}\text { Wind speed } \\
(\mathrm{km} / \mathrm{h})\end{array}$ & $\begin{array}{r}\text { Rain } \\
(\mathrm{mm})\end{array}$ \\
\hline CHO & 554 & 33.42 & 66.80 & - & - & - & - & - \\
OBS & 827 & 32.88 & 68.85 & 21.87 & 10.57 & 65.00 & 5.00 & 18.00 \\
TUN & 900 & 33.57 & 68.98 & 22.17 & 5.47 & 71.00 & 5.00 & 27.30 \\
CAC & 1237 & 33.17 & 69.17 & 20.57 & 7.90 & 63.30 & 10.00 & 20.80 \\
USP & 1830 & 32.60 & 69.33 & 21.76 & 2.56 & 56.33 & 8.00 & 6.30 \\
PTI & 2720 & 32.82 & 69.90 & 14.40 & 1.80 & 29.66 & 19.00 & 21.70 \\
\hline
\end{tabular}

whose geographical and climatic characteristics are described in Table 1 . The regions where the populations were sampled are shown in Fig. 1. Ten-year averages were used for the months of March, April and May for all five climatic variables analysed.

Populations were collected each April in 1991, 1992 and 1993, from the environmental region known as oasis cuyanos at lower altitudes, with its prevalence of shrubs and warm and dry climate, to the altoandina region at high altitudes, with its sparse vegetation consisting of shrubs and grasses and moderate to cold climate.

Methods of conservation of specimens and enzyme extractions are described by Confalonieri $e t$ al. (1990). Eight isozyme systems, belonging to groups I and II, were analysed. They gave sufficient loci to enable assessment of genetic variation. These systems were: esterase (EC 3.1.1.1; EST), lactate dehydrogenase (EC 1.1.1.27; LDH), superoxide dismutase (EC 1.15.1.1; SOD), peptidase (EC 3.4.11.11; PEP), glutamic-oxaloacetic transaminase (aspartate aminotransferase) (EC 2.6.1.1; GOT), malic enzyme (EC 1.1.1.40; $\mathrm{ME}$ ), malate dehydrogenase (EC 1.1.1.37; MDH) and leucyl aminopeptidase (EC 3.4.11.1; LAP).

Tray and gel buffer systems as well as staining procedures for EST, LDH, PEP, SOD and GOT are described by Confalonieri et al. (1990, 1992). The $\mathrm{ME}$ and MDH systems were as reported by Shaw \& Prassad (1970) and the LAP system as described by Saidman (1985).

For cytogenetic analysis the testes were dissected out prior to freezing, fixed in 1:3 acetic acid:ethanol and squashed in acetic orcein. Allelic frequencies of polymorphic loci with more than two alleles, including a null allele, were estimated following the method of Neimann-Sorensen (1956).

Genetic variability was estimated through the mean expected heterozygosity $(H)$ and the percentage of polymorphic loci $(P)(\mathrm{Nei}, 1975)$. The differ-

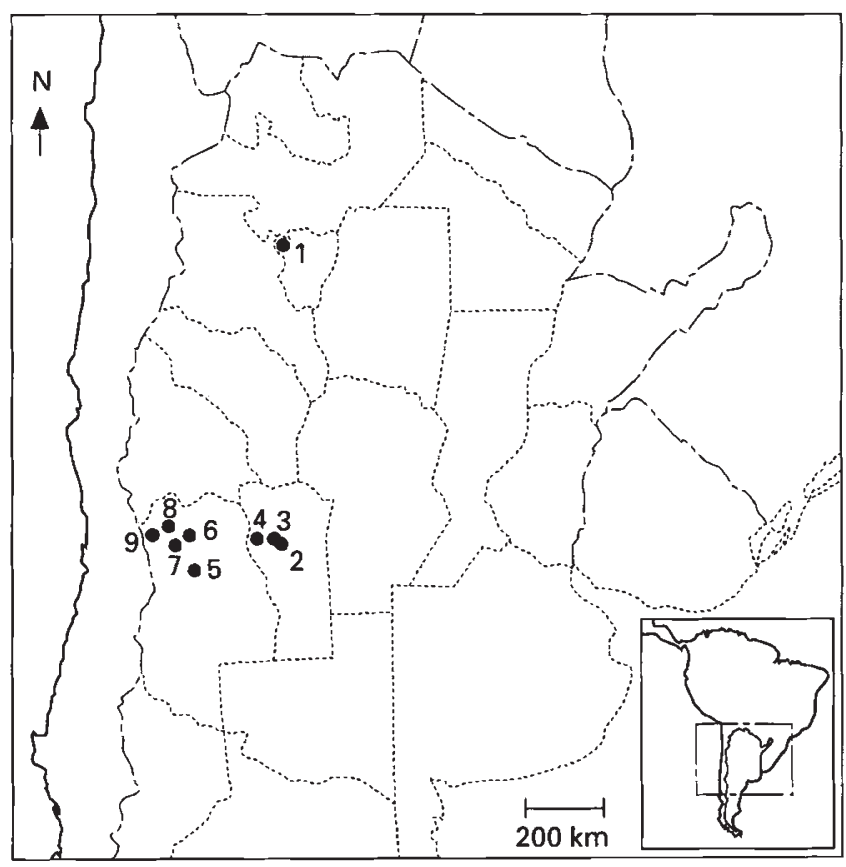

Fig. 1 Map showing the localities where the populations of Trimerotropis pallidipennis were sampled: (1) Ampimpa; (2) San Luis 1; (3) San Luis 2; (4) Chosmes; (5) Tunuyán; (6) Observatorio; (7) Cacheuta; (8) Uspallata; (9) Puente del Inca.

entiation between populations was measured by Nei's (1972) genetic distances $(d)$. The estimations of both $H$ and $d$ were made according to the methods described by Nei (1987), using the program GENIND (Vilardi, 1991).

Linkage disequilibria among enzymatic loci and chromosome sequences $(D)$ were calculated using the method of gene counting (Hill, 1974). To test for the significance of the value of $D$ for each $p \mu$ gamete, $\chi^{2}$ with one degree of freedom was used:

$$
\chi^{2}=n D p \mu^{2} /[p(1-p) \mu(1-\mu)]
$$


where $n$ is the number of individuals, $p$ is the frequency of the chromosome sequence, and $\mu$ is the frequency of the allele.

Population structure was analysed by means of $F$-statistics (Wright, 1951, 1965). The estimations were made according to the methods of Nei \& Chesser (1983).

Gene flow estimates were derived from $F_{\mathrm{ST}}$ values (Wright, 1931) by the relationship

$F_{\mathrm{ST}}=1 /(1+4 N m)$

and also by the method of Slatkin $(1981,1985)$ :

$N m=\frac{\exp \{-[\ln (p(1))+2.44] / 0.505\}}{n / 25}$

where $N$ is the effective population size, $N m$ is the number of migrants per generation, $p(1)$ is the average frequency of alleles found in single popula- tions (private alleles) and $n$ is the mean number of individuals sampled per population.

\section{Results}

\section{Isoenzymatic analysis}

A total of 19 loci were scored in all samples. The inheritance of bands corresponding to the $\mathrm{LDH}$, SOD, PEP and GOT systems has been described elsewhere (Confalonieri et al., 1990, 1992). MDH is coded by three loci $(M d h-1, M d h-2$ and $M d h-3)$ and $\mathrm{ME}$ by one $(\mathrm{Me}-1)$. For the LAP system, only an invariable band (LAP-1) could be analysed (locus Lap-1). Sod-1, Sod-6, Sod-7, Pep-1, Pep-2, Lap-1, Est-1, Got-2, Mdh-1, Mdh-2, Mdh-3 and $M e-1$ were all monomorphic for the same allele in all the sampled locations. The remaining loci were polymorphic, and their allelic frequencies are described in Table 2.

Table 2 Allelic frequencies of polymorphic loci corresponding to the samples analysed of Trimerotropis pallidipennis

\begin{tabular}{|c|c|c|c|c|c|c|c|c|c|c|c|c|c|}
\hline \multirow[b]{2}{*}{ Locus } & \multirow[b]{2}{*}{ Allele } & \multicolumn{2}{|c|}{$\mathrm{CHO}$} & \multicolumn{2}{|c|}{ OBS } & \multicolumn{2}{|c|}{ TUN } & \multicolumn{2}{|c|}{ CAC } & \multicolumn{2}{|c|}{ USP } & \multicolumn{2}{|c|}{ PTI } \\
\hline & & Freq. & $n$ & Freq. & $n$ & Freq. & $n$ & Freq. & $n$ & Freq. & $n$ & Freq. & $n$ \\
\hline$L d h-1$ & $\begin{array}{l}1 \\
2\end{array}$ & $\begin{array}{l}0.44 \\
0.56\end{array}$ & 24 & $\begin{array}{l}0.32 \\
0.68\end{array}$ & 25 & $\begin{array}{l}0.31 \\
0.69\end{array}$ & 26 & $\begin{array}{l}0.64 \\
0.36\end{array}$ & 14 & $\begin{array}{l}0.45 \\
0.55\end{array}$ & 21 & $\begin{array}{l}0.06 \\
0.94\end{array}$ & 9 \\
\hline Got-1 & $\begin{array}{l}1 \\
2 \\
3\end{array}$ & $\begin{array}{l}0.31 \\
0.69 \\
0.00\end{array}$ & 21 & $\begin{array}{l}0.27 \\
0.72 \\
0.02\end{array}$ & 30 & $\begin{array}{l}0.34 \\
0.66 \\
0.00\end{array}$ & 32 & $\begin{array}{l}0.10 \\
0.90 \\
0.00\end{array}$ & 26 & $\begin{array}{l}0.30 \\
0.70 \\
0.00\end{array}$ & 25 & $\begin{array}{l}0.23 \\
0.75 \\
0.02\end{array}$ & 28 \\
\hline Est-2 & $\begin{array}{l}1 \\
2\end{array}$ & $\begin{array}{l}0.56 \\
0.44\end{array}$ & 26 & $\begin{array}{l}0.34 \\
0.66\end{array}$ & 32 & $\begin{array}{l}0.00 \\
1.00\end{array}$ & 33 & $\begin{array}{l}0.19 \\
0.81\end{array}$ & 26 & $\begin{array}{l}0.29 \\
0.71\end{array}$ & 26 & $\begin{array}{l}0.60 \\
0.40\end{array}$ & 31 \\
\hline Est -3 & $\begin{array}{l}1 \\
2 \\
3\end{array}$ & $\begin{array}{l}0.50 \\
0.50 \\
0.00\end{array}$ & 22 & $\begin{array}{l}0.70 \\
0.30 \\
0.00\end{array}$ & 30 & $\begin{array}{l}0.64 \\
0.36 \\
0.00\end{array}$ & 21 & $\begin{array}{l}0.46 \\
0.54 \\
0.00\end{array}$ & 26 & $\begin{array}{l}0.46 \\
0.52 \\
0.02\end{array}$ & 25 & $\begin{array}{l}0.98 \\
0.02 \\
0.00\end{array}$ & 27 \\
\hline Est-4 & $\begin{array}{l}1 \\
2 \\
3 \\
4\end{array}$ & $\begin{array}{l}0.83 \\
0.17 \\
0.00 \\
0.00\end{array}$ & 26 & $\begin{array}{l}0.69 \\
0.31 \\
0.00 \\
0.00\end{array}$ & 21 & $\begin{array}{l}0.66 \\
0.08 \\
0.00 \\
0.26\end{array}$ & 25 & $\begin{array}{l}0.54 \\
0.46 \\
0.00 \\
0.00\end{array}$ & 25 & $\begin{array}{l}0.60 \\
0.38 \\
0.02 \\
0.00\end{array}$ & 24 & $\begin{array}{l}0.71 \\
0.22 \\
0.00 \\
0.07\end{array}$ & 29 \\
\hline Est -5 & $\begin{array}{l}1 \\
2 \\
3 \\
0\end{array}$ & $\begin{array}{l}0.00 \\
0.05 \\
0.00 \\
0.95\end{array}$ & 22 & $\begin{array}{l}0.00 \\
0.03 \\
0.08 \\
0.89\end{array}$ & 31 & $\begin{array}{l}0.00 \\
0.10 \\
0.07 \\
0.83\end{array}$ & 23 & $\begin{array}{l}0.00 \\
0.13 \\
0.17 \\
0.70\end{array}$ & 27 & $\begin{array}{l}0.00 \\
0.27 \\
0.25 \\
0.46\end{array}$ & 26 & $\begin{array}{l}0.00 \\
0.91 \\
0.09 \\
0.00\end{array}$ & 32 \\
\hline Est-6 & $\begin{array}{l}1 \\
2 \\
3 \\
0\end{array}$ & $\begin{array}{l}0.00 \\
1.00 \\
0.00 \\
0.00\end{array}$ & 22 & $\begin{array}{l}0.04 \\
0.88 \\
0.08 \\
0.00\end{array}$ & 26 & $\begin{array}{l}0.02 \\
0.98 \\
0.00 \\
0.00\end{array}$ & 23 & $\begin{array}{l}0.02 \\
0.65 \\
0.07 \\
0.26\end{array}$ & 27 & $\begin{array}{l}0.08 \\
0.58 \\
0.08 \\
0.27\end{array}$ & 26 & $\begin{array}{l}0.05 \\
0.16 \\
0.00 \\
0.80\end{array}$ & 32 \\
\hline$H$ & & 0.1229 & & 0.1374 & & 0.1165 & & 0.1562 & & 0.1918 & & 0.1051 & \\
\hline
\end{tabular}

$n$, number of individuals analysed. $H$, mean heterozygosity. 
Mean heterozygosities (Table 2) were not statistically different between populations $(t=0-0.4$; $P=0.5-0.3$ ). Differences in allelic frequencies were quantified by means of Nei's genetic distances. A cluster analysis (Fig. 2b) shows that populations are grouped according to their altitudinal distances and climatic characteristics. A matrix for Nei's coefficients between all of the pairs of T. pallidipennis samples $(6 \times 6)$ was constructed and it correlated with a matrix of differences in altitude and humidity conditions between the same samples, using Mantel's (1967) test for association. The values of the matrix correlations were in both cases significant (altitude, $r=0.87, P=0.009 ;$ humidity, $r=0.97$, $P=0.03$ ), which means that genetic distances tended to be higher if a pair of samples was collected from widely divergent altitudes and relative humidity conditions. However, according to the neutral theory, Nei's distances $(d)$ should be positively correlated with geographical distances $(G)$. Because in some cases more proximal populations are sited at similar altitudes, a test for an association between a matrix of $G$ and one of $d$ was also performed. Interestingly, as occurs with inversion frequencies (Confalonieri, 1994), this correlation was not significant $(r=0.12 ; P=0.38)$. Multiple regression analyses of all allelic frequencies on geographical (altitude, latitude and longitude) and climatic (maximum and minimum temperature, humidity, wind and rain) variables showed that the Est-5 and Est-6 loci are strongly correlated with altitude and

(a)

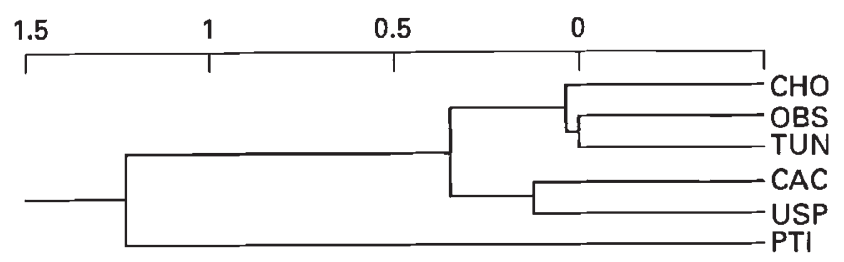

(b)

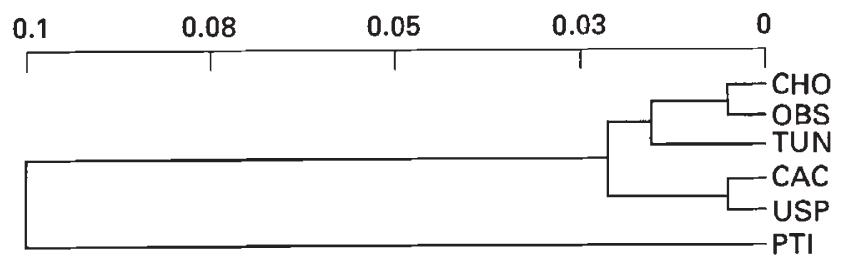

Fig. 2 Phenograms constructed for Trimerotropis pallidipennis from Nei's genetic distances using the UPGMA method of cluster analysis. Data are (a) chromosome frequencies, and (b) allozyme frequencies. humidity (Table 3, Fig. 4). These associations would mostly explain the phenograms obtained for genetic distances (Fig. 2). This clinal variation is so marked that it is qualitatively evident when zymograms from populations situated at the extremes of the gradients (but separated by only $\approx 200 \mathrm{~km}$ ) are compared: in Puente del Inca ( $2720 \mathrm{~m}$ above sea level) Est $-5^{2}$ and Est $-6^{\circ}$ are almost fixed whereas in Tunuyán $(900 \mathrm{~m})$ the relationship is the inverse (Fig. 3).

\section{Population structure}

Table 4 shows the $F$-statistics obtained for polymorphic loci. Except for Got-1 and $L d h-1$, populations may be considered as panmictic because $F_{\text {Is }}$ values of most loci are not statistically different from 0 . In agreement with Nei's genetic distances, differentiation measured through $F_{\mathrm{ST}}$ values was very high in all cases except Got-1, with a mean $F_{\mathrm{ST}}$ value of 0.18 .

The estimates of gene flow between populations through $F_{\mathrm{ST}}$ values are $N m=1.17$ (considering all loci), and $\mathrm{Nm}=2.35$ (without considering Est-5 and Est-6 loci). Using the distribution of private alleles it is much higher: $N m=18$. These discrepancies are discussed further.

\section{Cytological analysis}

The male karyotype of $T$. pallidipennis consists of 23 chromosomes $(22+\mathrm{XO})$. Pairs $1-3$ are large, pairs 4-8 are medium-sized and pairs $9-11$ are small. All three large chromosomes are submetacentric (SM), the $\mathrm{X}$ is metacentric (M) and the remaining chromosomes are basically acrocentric (A) (Vaio et al., 1979).

Pairs 4, 6, 7 and 8 are polymorphic for six or seven (depending on the population sampled) pericentric inversions that change the basic acrocentric

Table 3 Regression for Trimerotropis pallidipennis of allelic frequencies of esterase loci on altitude and humidity

\begin{tabular}{|c|c|c|c|c|c|}
\hline \multirow[b]{2}{*}{ Locus } & \multirow[b]{2}{*}{ Allele } & \multicolumn{2}{|c|}{ Altitude } & \multicolumn{2}{|c|}{ Humidity } \\
\hline & & $R$ & $P$ & $R$ & $P$ \\
\hline Est-6 & 2 & -0.941 & 0.0008 & 0.904 & 0.0084 \\
\hline Est-6 & 0 & 0.904 & 0.0023 & -0.919 & 0.0065 \\
\hline Est-5 & 2 & 0.861 & 0.0048 & -0.936 & 0.0046 \\
\hline Est-5 & 0 & -0.992 & $<0.0001$ & 0.987 & 0.0099 \\
\hline
\end{tabular}

$R$, proportion of the variance explained by the regression (the sign indicates the slope of the regression line).

$P$, level of significance. 


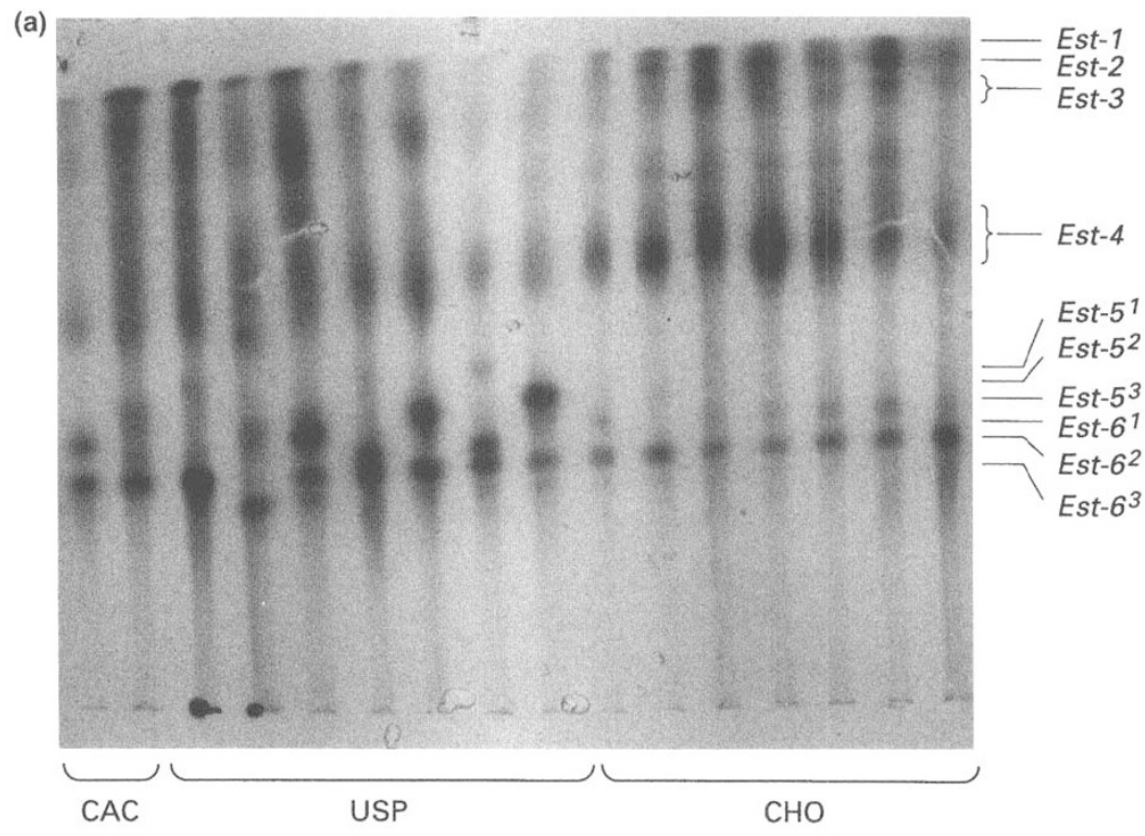

(b)

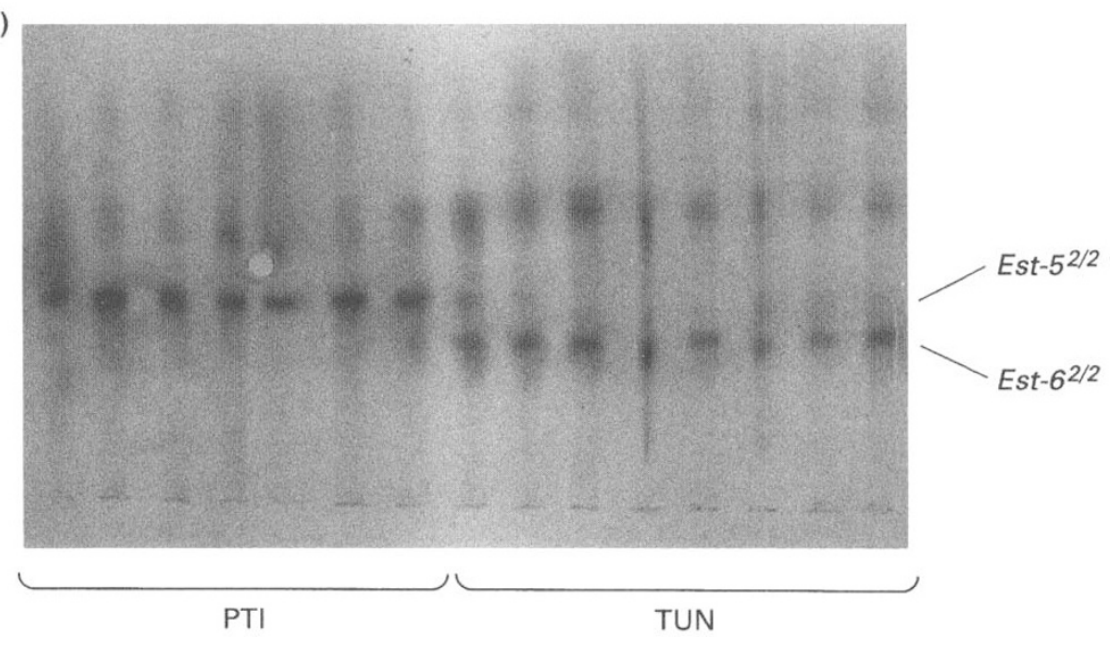

Fig. 3 Some of the observed allozyme phenotypes for the esterase system of Trimerotropis pallidipennis observed in the populations of Cacheuta (CAC), Uspallata (USP), Chosmes (CHO), Puente del Inca (PTI) and Tunuyán (TUN). Only bands corresponding to alleles of the Est-5 and Est-6 loci are indicated (a more detailed analysis of this system is given by Confalonieri et $a l ., 1990)$. (a) lane 1: individual with genotype $E s t-5^{3 / 3}$ or ${ }^{3 / 0}$, Est $-6^{2 / 2}$ or ${ }^{2 / 6}$; lane 5: genotype Est-5 ${ }^{2 / 3}$, Est $-6^{2 / 3}$; lane 6: genotype Est-5/10 Est-6 $6^{1 / 2}$. (b)

Zymogram showing the great differentiation in enzymatic expression between PTI and TUN. In PTI the prevailing genotype is Est $^{-5^{2 / 2}}$, Est- $6^{0 / 0}$, whereas in TUN it is Est ${ }^{0 / 0}, E_{s t-6^{2 / 2}}$. morphology into many SM (SM1, SM2, SM3 and SM4) and metacentric forms (Confalonieri \& Colombo, 1989).

Table 5 shows the frequencies of all chromosome morphologies corresponding to the six samples. As previously observed for other groups of populations sampled (Confalonieri \& Colombo, 1989; Confalonieri, 1994), clinal variation is present again for most chromosomal morphologies: inverted sequences tend to increase towards lower altitudes and eastern longitudes whereas basic sequences follow the inverse tendency and are fixed in Puente del Inca (at the highest altitude).

Nei's genetic distances for chromosome frequencies were estimated and the phenogram constructed gave almost identical results to the allozyme frequencies (Fig. 2a). These similarities are most probably caused by the esterase loci. As the frequencies of these loci show similar patterns of variation, possible linkage disequilibria between them and some of the inverted regions are not unlikely. When allele and chromosome frequencies are plotted in parallel as a function of altitude, it emerges that the esterase loci show patterns of clinal variation similar to chromosomes 4 and 8 (Fig. 4). Therefore, alleles of these loci may well be enclosed within chromosomes 4 or 8 . The existence of more than two alleles and two chromosome sequences implies many haplotypic combinations, so the number of individuals which need to be sampled in order to achieve statistically significant values of linkage disequilibrium is very high. Besides, dominance between 
alleles of the Est-5 and Est-6 loci (i.e. null alleles) did not allow distinction of homozygotes from heterozygotes other than in some samples such as in Cacheuta, where the low frequency of the Est $-5^{2}$ allele implied that active bands corresponded to heterozygote individuals. In this population, the value of $D$ between chromosome 4 and the Est-5
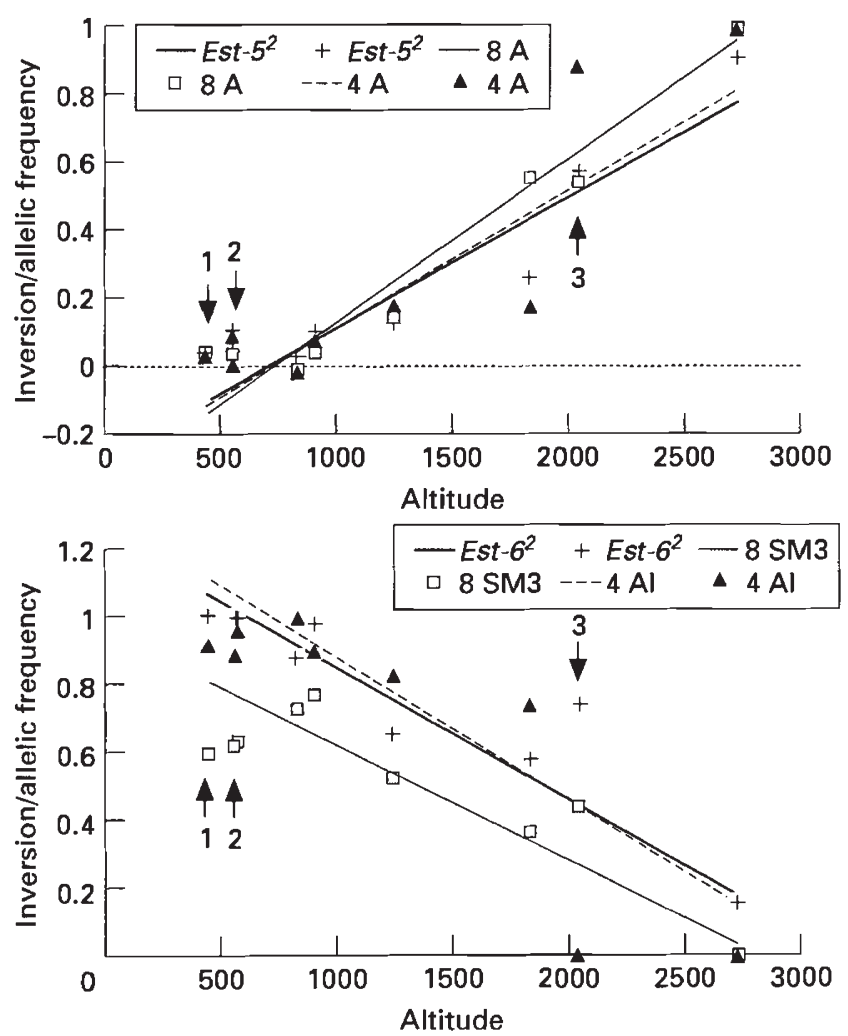

Fig. 4 Parallel plots of allelic $\left(E s t-5^{2}\right.$ and Est $\left.-6^{\circ}\right)$ and chromosome (4 A and $8 \mathrm{~A}$ ) frequencies for Trimerotropis pallidipennis as a function of altitude. The arrows indicate the 1988 samples: (1) San Luis 1; (2) San Luis 2; and (3) Ampimpa.

Table 4 Fixation indices for the seven polymorphic loci analysed for Trimerotropis pallidipennis

\begin{tabular}{lrccc}
\hline Locus & \multicolumn{1}{c}{$F_{\text {IS }}$} & $P$ & $F_{\text {ST }}$ & $P$ \\
\hline Ldh -1 & 0.179 & 0.051 & 0.111 & $<0.001$ \\
Got -1 & 0.256 & 0.001 & 0.013 & $>0.5$ \\
Est -2 & 0.014 & 0.862 & 0.178 & $<0.001$ \\
Est -3 & -0.016 & 0.862 & 0.125 & $<0.001$ \\
Est -4 & 0.018 & 0.823 & 0.053 & $<0.001$ \\
Est -5 & 0.037 & 0.639 & 0.386 & $<0.001$ \\
Est -6 & -0.022 & 0.791 & 0.364 & $<0.001$ \\
\hline
\end{tabular}

$P$, level of significance.

(C) The Genetical Society of Great Britain, Heredity, 76, 346-354. locus was not significant $\left(D=-0.01 ; \chi_{1}^{2}=0.26\right)$. However, linkage disequilibrium estimates between chromosome 8 and Est-5 were: $D_{q \mu}=-0.05$, $D_{r \mu}=0.025$ and $D_{p \mu}=0.025 ; q, r$ and $p$ representing the sequences $8 \mathrm{~A}, 8 \mathrm{SM} 4$ and $8 \mathrm{SM} 3$, respectively, and $\mu$ the $E s t-5^{0}$ allele. In this case, $D_{q \mu}$ was statistically significant $\left(\chi_{1}^{2}=6.17, P<0.05\right)$, so the basic sequence would be in negative linkage disequilibrium with the Est-5 ${ }^{0}$ allele as expected for the parallel distribution of both variables.

\section{Discussion}

Nevo et al. (1984) concluded that some biotic variables, mainly ecological, are generally correlated with the level of heterozygosity $(H)$. Particularly, nonterritorial species and those which are distributed over variable climatic regions show greater levels of $H$ than those territorial species which are found in marginal ecological habitats. Trimerotropis pallidipennis exhibits nonterritorial behaviour (Otte \& Joern, 1975). Although it is distributed over arid and semiarid regions, in South America it shows a greater ecological amplitude, along a wider altitudinal range, than populations from North America (John, 1983). Therefore, the high values of $H$ obtained for the samples reported here (13 per cent, in comparison with other insects that have a mean $H$ of 7 per cent), and for other populations previously assayed (Confalonieri et al., 1992) concur with the relationship with the ecological conditions of this species, as suggested by Nevo et al. (1984).

This high level of variability is in part explained by esterase loci. Est-5 and Est-6 frequencies depend

Table 5 Chromosome frequencies observed in all populations of Trimerotropis pallidipennis analysed along the gradient for medium chromosomes numbers 4, 6, 7 and 8

Chromosome

Number Morphology CHO OBS TUN CAC USP PTI

\begin{tabular}{llllllll}
\hline 4 & A & 0.11 & 0 & 0.069 & 0.173 & 0.184 & 1 \\
4 & AI & 0.89 & 1 & 0.899 & 0.827 & 0.739 & 0 \\
4 & SM1 & 0 & 0 & 0.031 & 0 & 0.076 & 0 \\
6 & M & 0.84 & 0.59 & 0.641 & 0.333 & 0.136 & 0 \\
7 & SM2 & 0.88 & 0.818 & 0.719 & 0.405 & 0.046 & 0 \\
8 & A & 0.04 & 0 & 0.047 & 0.143 & 0.561 & 1 \\
8 & SM3 & 0.62 & 0.727 & 0.766 & 0.524 & 0.364 & 0 \\
8 & SM4 & 0.34 & 0.273 & 0.188 & 0.333 & 0.076 & 0 \\
\hline
\end{tabular}

A, basic acrocentric; AI, inverted acrocentric; $M$, metacentric; SM1-SM4, submetacentrics. 
significantly on altitude and relative humidity, as do many chromosomal sequences.

The frequent association of inversion polymorphisms with particular environments is sometimes explained on the basis of the ability of some inversions to generate coadapted supergenes which are maintained by selection (Dobzhansky et al., 1980). Trimerotropis pallidipennis is endemic to western North America but has also dispersed southwards. Its basic requirement appears to be the prevalence of arid and semiarid conditions (Vaio et al., 1979), which are characteristics of only the western regions of America and Patagonia. According to White (1973) colonization of southern latitudes by $T$. pallidipennis occurred from North American populations with basic chromosome arrangements, presumably along the high Andean lands of South America. Here, it extended its distribution to lower altitudes (Vaio et al., 1979) where inversion sequences appeared in polymorphic or fixed states. Chromosomal clines observed in T. pallidipennis might be the consequence of secondary contacts, as occurs in other grasshopper species (Hewitt, 1988; Shaw et al., 1980 ), or of geographically variable selection. The former process requires that all populations at lower altitudes had remained isolated after colonization and fixed for the same inverted sequences of chromosomes 4, 6, 7 and 8 either by chance or by deterministic forces.

Selection of some sort is more likely to act, because of the repetition of patterns of variation over a wide geographical area and stability over time (Confalonieri \& Colombo, 1989, 1992; Confalonieri, 1994; this report). If current clines are hybrid zones, selection could be acting against recombinant genotypes based on inversion types. However, as the populations are all polymorphic except for some sited at the very extremes of the distribution of the species along arid and semiarid regions of Argentina (Goñi et al., 1985; Confalonieri, 1994) the width of the hybrid zone would seem to be too extensive. Therefore, we favour the hypothesis of geographically variable selection maintaining the clines.

The most important results reported here are the almost identical phenograms constructed with Nei's genetic distances obtained from allozyme and chromosome data. These are explained in part by the patterns of variation of esterase loci which match those of chromosome frequencies, probably as a consequence of linkage. Interestingly, similar distributions of Est-5 and Est-6 alleles were observed for other populations of T. pallidipennis collected in 1988 , in spite of one of them being separated by a great distance $(\approx 800 \mathrm{~km})$ (Confalonieri et al., 1990).
One of these samples (Ampimpa) came from the 'Prepuna' biogeographical province and at $2040 \mathrm{~m}$ above sea level, whereas the other two (San Luis 1 and San Luis 2) were from the Chaco province at 440 and $560 \mathrm{~m}$ above sea level (Fig. 1). All three populations showed allelic frequencies for esterase loci that agreed with their altitudinal situation according to the clinal variation reported here (Fig. 4). Indeed, they can be included in the regression analysis as if they were part of the relationship analysed here, and the dependence of the allelic frequencies on altitude is still highly significant $\left(r=0.93, \quad P=2.9 \times 10^{-4}\right.$ for Est $5^{2} ; \quad r=-0.92$, $P=4 \times 10^{-4}$ for Est $\left.6^{2}\right)$.

Trimerotropis pallidipennis is an $r$-strategist (Wallner, 1987). Insects that are $r$-strategists have high capacities for population increase, are poor competitors, have a high incidence of polymorphism and high levels of vagility (Wallner, 1987). This last characteristic and the fact that they are strong flyers suggest a high value of $\mathrm{Nm}$.

Gene flow estimates from either $F_{\text {ST }}$ or rare alleles are based on the same evolutionary models, which assume migration and drift of neutral genetic variants among equally accessible demes. Both statistics should provide roughly equally accurate estimates of $\mathrm{Nm}$ under a wide variety of conditions, including different kinds of selection (Slatkin \& Barton, 1989). The discrepancy between the two estimates may result from the fact that the second method requires a reasonable number of private alleles to be present whereas $F_{\mathrm{ST}}$ can be estimated from data from any polymorphic loci (Slatkin \& Barton, 1989). Although high values of $\mathrm{Nm}$ were expected for T. pallidipennis, we prefer the estimation made using Wright's coefficient, which does not include loci that show clinal variation; i.e. 2.35 migrants per generation.

Johnson (1974) proposed that esterase polymorphisms might reflect the variation of substrates in the environment. Esterase enzymes frequently act on external substrates following ingestion. Trimerotropis pallidipennis feeds on annual plants associated with species of the genus Larrea (creosote bush) (Otte \& Joern, 1975; Wallner, 1987); in Argentina one of these plant species is Kochia scoparia (L.) Schrad. (the alfalfa criolla). If esterase loci are located within the inversion, it is plausible that either they would experience cumulative selection acting on all of the loci in that stretch of DNA, or that Est-5 and Est-6 loci would be the target of selection, being adapted for the digestion of esters characteristic of plants which grow at different altitudes. The definitive answer would be obtained by rearing grasshoppers in uniform environments. 
Bearing in mind the results obtained from the analysis of the correlation between esterase frequency and chromosome frequency, it is proposed that they would comprise part of a supergene most probably belonging to the medium chromosome 8 . The inverse relationship observed between the two active forms of both loci $\left(E s t-5^{2}\right.$ and Est $\left.-\sigma^{2}\right)$ suggests that they could be coadapted into this supergene.

\section{Acknowledgements}

We acknowledge Dr Nick Barton who kindly provided useful suggestions after reading the original version of this manuscript. The authors also wish to express their sincere gratitude to $\mathrm{Dr} \mathrm{J} . \mathrm{H}$. Hunziker for his constant encouragement and helpful discussions. They are also indebted to M. E. Mulgura de Romero from the Instituto de Botánica Darwinion for the taxonomic determination of Kochia scoparia, and to Lic. Juan Margarit for helping during the collection of some of the samples. Financial support from the Consejo Nacional de Investigaciones Científicas y Técnicas, Secretaría de Ciencia y Técnica and Universidad de Buenos Aires (Argentina) through grants to Drs J. H. Hunziker and J. C. Vilardi is also acknowledged.

\section{References}

CONFALONIERI, v. A. 1988. Effects of centric shift polymorphisms on chiasma conditions in Trimerotropis pallidipennis. Genetica, 76, 171-179.

CONFALONIERI, v. A. 1994. Inversion polymorphisms and natural selection in Trimerotropis pallidipennis (Orthoptera): correlations with geographical variables. Hereditas, 121, 79-86.

CONFALONIERI, V. A. AND COLOMBO, P. C. 1989. Inversion polymorphisms in Trimerotropis pallidipennis (Orthoptera): clinal variation along an altitudinal gradient. Heredity, 62, 107-112.

CONFAlONIERI, v. A., AND COLOMBO, P. C. 1992. Polimorfismos de inversión y selección natural en Trimerotropis pallidipennis: correlación con variables climáticas. Actas XXIII Congreso Argentino de Genética, p. 20.

CONFALONIERI, V. A., VILARDI, J. C., AND SAIDMAN, B. O. 1990. Esterase variation among Argentine populations of Trimerotropis pallidipennis (Orthoptera). Génét. Sél. Évol., 22, 279-288.

CONFALONIERI, V. A., VILARDI, J. C. AND SAIDMAN, B. O. 1992. Allozyme variation between chromosomally differentiated populations of Trimerotropis pallidipennis (Orthoptera). Evolución Biológica, 6, 39-51.

DOBZHANSKY, T., AYALA, F., STEBBINS, G.L. AND VALENTINE, J. W. 1980. Evolución. Ediciones Omega, S.A. Barcelona.

GOÑI, B., DE VAIO, E. S., BELTRAMI, M., LEIRA, M. S., CRIVEL,
M., PANZERA, F., CASTEllanos, P. AND BASSO, A. 1985. Geographic patterns of chromosomal variation in populations of the grasshopper (Trimerotropis pallidipennis) from southern Argentina. Can. J. Genet. Cytol., 27, 259-271.

HEWITT, G. M. 1988. Hybrid zones:natural laboratories for evolutionary studies. Trends Ecol. Evol., 3, 158-167.

HILL, W. G. 1974. Estimation of linkage disequilibrium in randomly mating populations. Heredity, 33, 229-239.

JOHN, B. 1983. The role of chromosome change in the evolution of orthopteroid insects. In: Sharma A.K. and Sharma A.N. (eds) Chromosomes in the Evolution of Eukaryotic Groups, vol. 1, pp. 1-114. CRC Press, Boca Raton, FL.

JOHNSON, G. B. 1974. Enzyme polymorphism and metabolism. Polymorphisms among enzyme loci is related to metabolic function. Science, 184, 28-37.

MANTEL, N. A. 1967. The detection of disease clustering and a generalized regression approach. Cancer Res., 27, 209-220.

MESA, A. 1971. Polimorfismo cromosómico en Trimerotropis pallidipennis (Orthoptera-Acridoidea-Oedipodinae). Rev. Peru Ent., 14, 229-233.

NEI, M. 1972. Genetic distances between populations. Am. Nat., 106, 283-292.

NEI, M. 1975. Molecular Population Genetics and Evolution. North-Holland/American Elsevier, Amsterdam.

NEI, M. 1987. Molecular Evolutionary Genetics. Columbia University Press, New York.

NEI, M. AND CHESSER, R. 1983. Estimation of fixation indices and gene diversities. Ann. hum. Genet., 47, 253-259.

NEIMANN-SORENSEN, A. 1956. Blood groups and breed structure as exemplified by three Danish breeds. Acta Agric. Scand., 6, 115-137.

NEVO, E., BEILES, A. AND BEN-SHLOMO, R. 1984. The evolutionary significance of genetic diversity: ecological, demographic and life history correlates. In: Mani, G. S. (ed.) Lecture Notes in Biomathematics 53: Evolutionary Dynamics of Genetics Diversity, pp. 13-213. SpringerVerlag, New York.

OTTE, D. AND JOERN, A. 1975. Insect territoriality and its evolution: population studies of desert grasshoppers on creosote bushes. J. Anim. Ecol., 44, 29-54.

SAIDMAN, B. O. 1985. Estudios Isoenzimáticos en Especies del Género Prosopis. Ph.D. Thesis, Universidad de Buenos Aires.

SHAW, C. AND PRASSAD, R. 1970. Starch electrophoresis of enzymes. A compilation of recipes. Biochem. Genet., 4, 279-320.

SHAW, D., MORAN, C. AND WILKINSON, P. 1980. Chromosomal reorganization, geographic differentiation and the mechanism of speciation in the genus Caledia. In: Blackmann, R. L., Hewitt, G. M. and Ashburner, M. (eds) Insect Cytogenetics, pp. 171-194. Blackwell Scientific Publications, Oxford.

SLATKIN, M. 1981. Estimating levels of gene flow in natural populations. Genetics, 99, 323-335.

SLATKIN, M. 1985. Rare alleles as estimators of gene flow. 
Evolution, 39, 53-65.

SLATKIN, M. AND BARTON, N. H. 1989. A comparison of three indirect methods for estimating average levels of gene flow. Evolution, 43, 1349-1368.

Vilardi, J. C. 1991. Programa basic para estimar índices de distancias y variabilidad genética y sus errores a partir de muestras pequeñas. Mendeliana, 9, 67-68.

WALLNER, W. E. 1987. Factors affecting insect population dynamics: differences between outbreak and non-outbreak species. Ann. Rev. Ent., 32, 317-340.

WHITE, M. J. D. 1951. Cytogenetics of orthopteroid insects.
Adv. Genet., 4, 267-330.

WHite, M. J. D. 1973. Animal Cytology and Evolution, 3rd edn. Cambridge University Press, New York.

WRIGHT, s. 1931. Evolution in Mendelian populations. Genetics, 16, 97-159.

WRIGHT, s. 1951. The genetical structure of populations. Ann. Eugen., 15, 323-354.

WRIGHT, s. 1965. The interpretation of population structure by F-statistics with special regard to systems of mating. Evolution, 19, 395-420. 